Article

\title{
Butylated Hydroxytoluene Analogs: Synthesis and Evaluation of Their Multipotent Antioxidant Activities
}

\author{
Wageeh A. Yehye ${ }^{1}$, Noorsaadah Abdul Rahman ${ }^{1}$, Abeer A. Alhadi ${ }^{1}$, Hamid Khaledi ${ }^{1}$, \\ Seik Weng Ng ${ }^{1,2}$ and Azhar Ariffin ${ }^{1, *}$
}

1 Department of Chemistry, Faculty of Science, University of Malaya, Kuala Lumpur 50603, Malaysia

2 Chemistry Department, Faculty of Science, King Abdulaziz University, P.O. Box 80203, Jeddah 21589, Saudi Arabia

* Author to whom correspondence should be addressed; E-Mail: azhar70@um.edu.my; Tel.: +603-7967-4080.

Received: 9 April 2012; in revised form: 1 June 2012 / Accepted: 12 June 2012 /

Published: 25 June 2012

\begin{abstract}
A computer-aided predictions of antioxidant activities were performed with the Prediction Activity Spectra of Substances (PASS) program. Antioxidant activity of compounds 1, 3, 4 and 5 were studied using 1,1-diphenyl-2-picrylhydrazyl (DPPH) and lipid peroxidation assays to verify the predictions obtained by the PASS program. Compounds 3 and 5 showed more inhibition of DPPH stable free radical at $10^{-4} \mathrm{M}$ than the well-known standard antioxidant, butylated hydroxytoluene (BHT). Compound 5 exhibited promising in vitro inhibition of $\mathrm{Fe}^{2+}$-induced lipid peroxidation of the essential egg yolk as a lipid-rich medium $\left(83.99 \%, \mathrm{IC}_{50} 16.07 \pm 3.51 \mu \mathrm{M} / \mathrm{mL}\right)$ compared to $\alpha$-tocopherol $\left(\alpha-\mathrm{TOH}, 84.6 \%, \mathrm{IC}_{50} 5.6 \pm 1.09 \mu \mathrm{M} / \mathrm{mL}\right)$. The parameters for drug-likeness of these BHT analogues were also evaluated according to the Lipinski's "rule-of-five" (RO5). All the BHT analogues were found to violate one of the Lipinski's parameters $(\log P>5)$, even though they have been found to be soluble in protic solvents. The predictive polar surface area (PSA) and absorption percent (\% ABS) data allow us to conclude that they could have a good capacity for penetrating cell membranes. Therefore, one can propose these new multipotent antioxidants (MPAOs) as potential antioxidants for tackling oxidative stress and lipid peroxidation processes.
\end{abstract}


Keywords: butylated hydroxyltolouene; drug-likeness properties; DPPH; lipid peroxidation; multipotent antioxidant; rule-of-five; PASS and activity prediction; thiosemicarbazide; 1,2,4-triazole; 1,3,4-thiadiazole

\section{Introduction}

Reactive oxygen species (ROS) are generally considered responsible for many cell disorders and the development of many undesired processes, including aging [1], inflammatory [2] and many others [3-7]. Phenolic primary antioxidants are the most active dietary antioxidants [8]. The commonly used synthetic antioxidants in foods are butylated hydroxyanisole (BHA) [9], butylated hydroxytoluene (BHT) [10] (Figure 1).

Figure 1. Chemical structures of compounds BHA, BHT, 1 and 2.

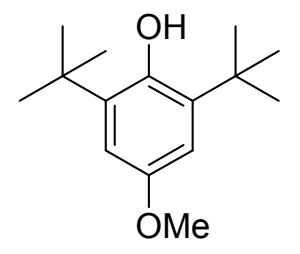

BHA<smiles>Cc1cc(C(C)(C)C)c(O)c(C(C)(C)C)c1</smiles>

$\mathrm{BHT}$

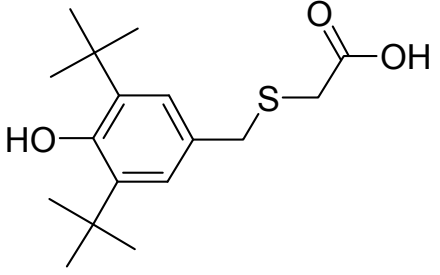

1

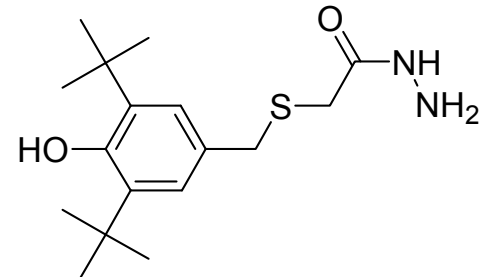

2

BHT (CAS 128-37-0; NCI C03598) was patented in 1947 [11]. It was found that two tert-butyl groups flanking the $\mathrm{OH}$ group are required to retain in vivo anti-inflammatory potency [12]. Following the same route, researchers of Parke-Davis have disclosed a new class of potent, selective and orally active COX-2 inhibitors incorporating the 2,6-di-tert-butyl phenol moiety, such as PD 164387 and PD 138387 (Figure 2) $[13,14]$.

Figure 2. Parke-Davis COX-2 inhibitors.

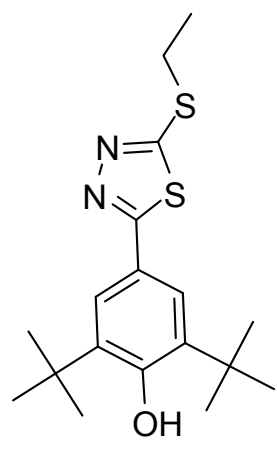

PD 164387<smiles>CONC1NC(=O)/C(=C/c2cc(C(C)(C)C)c(O)c(C(C)(C)C)c2)S1</smiles>

PD 138387

Based on the Parke-Davis COX-2 inhibitors, researchers have investigated their SAR to improve COX-2 selective inhibitors containing a 2,6-di-tert-butylphenol substituent as an antioxidant moiety [15]. Their selectivity might be related to their free-radical scavenging potency [15]. 
On the other hand, sterically hindered phenols linked with heterocyclic rings have also been extensively studied as dual COX/5-LOX inhibitors [16-18]. A combination of radical scavenging properties and anti-inflammatory activity has already been proven for a number of non-steroidal anti-inflammatory drugs (NSAIDs) [19,20]. However, BHT derivatives have become attractive antioxidant or co-antioxidant groups [21]. Therefore, it is no surprise that BHT has been modified to prepare a series of new antioxidants having new medicinal properties in the pharmaceutical industry $[12,22,23]$. Recently, qualitative SARS and rational-design strategies for antioxidants have been used to combine multiple functions; including various multiple antioxidant properties such as radical-scavenging ability and diversified pharmacological activities to offer hybrid compounds, which can exert multiple pharmacological functions through one molecular framework [24-26].

Thiosemicarbazides have been reported to show antibacterial [27], antimicrobial [28,29], anti-toxoplasmagondii [29] and antioxidant [30] activities. To date acyl derivatives of thiosemicarbazide bearing BHT moiety have been rarely synthesized.

Compounds containing the 1,3,4-thiadiazole nucleus have a wide range of pharmacological activities that include antimicrobial [31], antitubercular [32], anticancer [33,34] and antioxidant [35] properties.

1,2,4-Triazoles are an important class of five membered heterocyclic compounds. 1,2,4-Triazole-5thiones are known for their anti-inflammatory [36], selective COX-2 inhibitor [37] and antimycotic [38] and antioxidant [35] activity.

Regarding the effect of $m$-substituents, Tetsuto et al. [39] have evaluated the antioxidant activity of different donating substituents on a $m$-substituted phenol, and found that the $m$-substituent does not influence the antioxidant activity of a phenol at all. This is probably because a $m$-substituent shows only a small resonance effect. In contrast to this fact, previous reports found that heterocyclic systems with a halogen substituted at the $m$-position show greater antioxidant properties than those with other substituents [40,41].

Since we could not find any reports on the use of electron withdrawing groups to enhance the antioxidant activity of BHT, therefore, we used MPAO as an effective strategy to enhance the antioxidant activity of BHT even if a strong electron withdrawing group ( $m$-fluoro substituent) is a basic part of the hybrid molecule.

In the present study four BHT derivatives have been synthesized. The acid-(base-)catalyzed intramolecular dehydrative cyclization reaction of acylthiosemicarbazide $\mathbf{3}$ to the corresponding 1,3,4-thiadiazole 4 and 1,2,4-triazole 5 are described. Synthesized compounds have been characterized by IR, NMR and mass spectral analysis. X-ray structures of $\mathbf{3}$ and $\mathbf{4}$ will be further discussed in this paper. Potential biological effects of new compounds were predicted based on structure-activity relationships with the PASS software. Antioxidant activities predicted by the PASS program were experimentally verified by DPPH and TBARS (thiobarbituric acid reactive substance) assays. Furthermore, a computational study for prediction of absorption, distribution (ADMET) [42] properties of the synthesized compounds was performed by determination of polar surface area (PSA), absorption (ABS) and Lipinski parameters. 


\section{Results and Discussion}

\subsection{Chemistry}

Carboxylic acid 1 (Figure 1) was synthesized according to an established solvent-free procedure [43] through the reaction between 2,6-di-tert-butyl-phenol with formaldehyde and thioglycolic acid in the presence of di- $n$-butylamine. Hydrazide 2 (Figure 1) was synthesized using the indirect hydazination method through the reaction of 3,5-di-t-butyl-4-hydroxybenzyl chloride with the sodium salt of thioglycolic acid hydrazide [44].

The synthesis of thiosemicarbazide 3, 1,3,4-thiadiazole 4 and 1,2,4-triazole 5, described in this study are outlined in Scheme 1. Acid hydrazide 2 was treated with 3-fluorophenylisothiocyanate to give the corresponding acylthiosemicarbazide 3 in good yield. Compound $\mathbf{3}$ under acidic and basic conditions gave thiadiazole 4 and triazole 5, respectively. The structure of the synthesized compounds was confirmed based on their physical and spectral data. The structures of compounds $\mathbf{3}$ and $\mathbf{4}$ were further confirmed by X-ray crystallography.

Scheme 1. Synthesis of compounds 3-5.
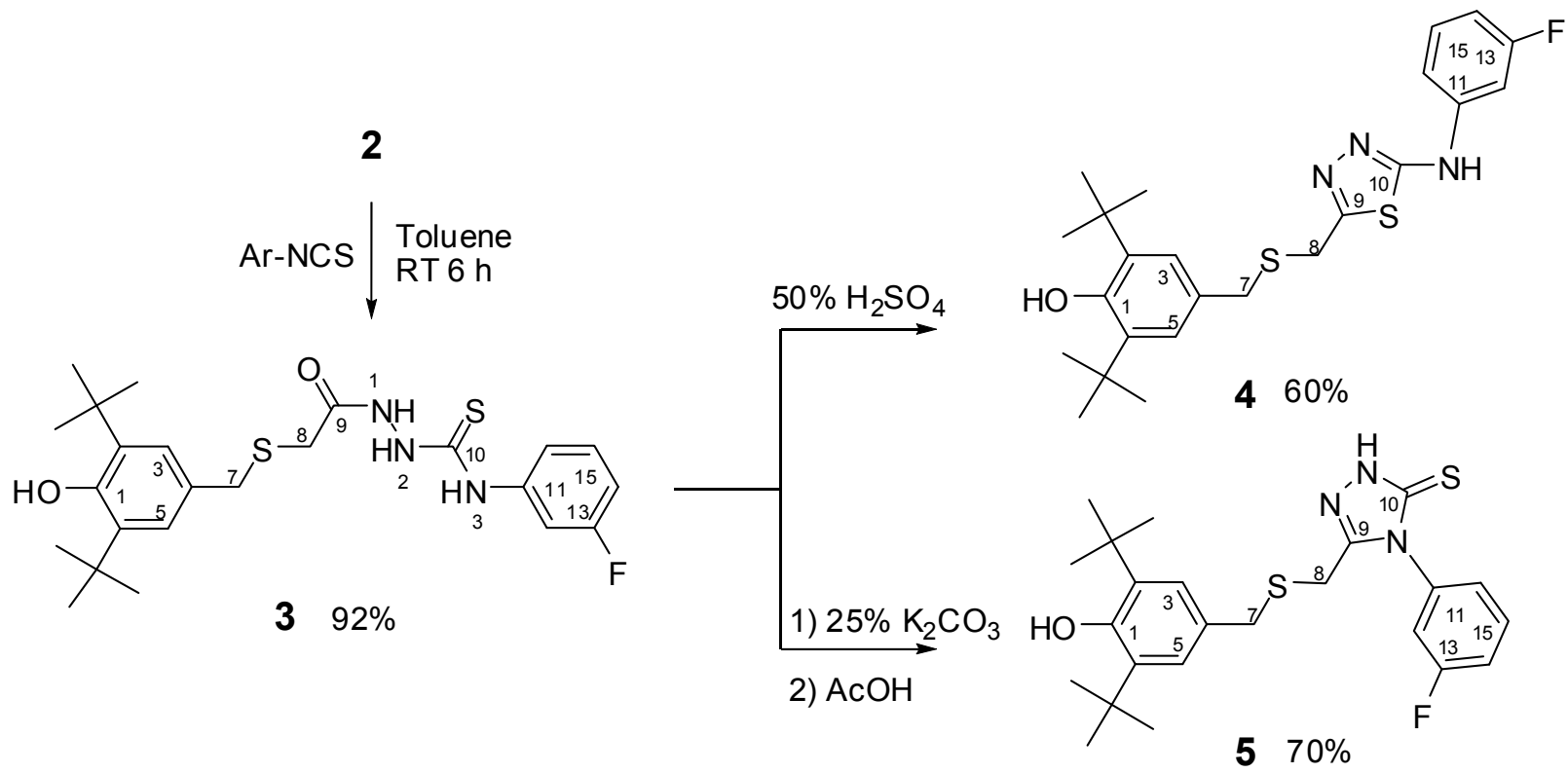

The IR spectra of all synthesized compounds showed strong absorptions at 3,623-3,653 cm $\mathrm{cm}^{-1}$, attributed to free $v($ Ar-O-H). Acylthiosemicarbazide 3 showed $\mathrm{NH}$ stretching bands between $3,285-3,340 \mathrm{~cm}^{-1}$, a $\mathrm{C}=\mathrm{O}$ stretching band at $1,713 \mathrm{~cm}^{-1}$, and did not show any $v(\mathrm{~S}-\mathrm{H})$ band at $2,570 \mathrm{~cm}^{-1}$, while the presence of a $\mathrm{C}=\mathrm{S}$ stretching band at $1,248 \mathrm{~cm}^{-1}$ indicated that 3 exists in the thione form in the solid-state [45,46]. Compound 4 showed two $\mathrm{C}=\mathrm{N}$ stretching bands at 1,616 and 1,610 $\mathrm{cm}^{-1}$ attributed to the presence of the thiadiazole ring $\mathrm{C}=\mathrm{N}$. Compound 5 did not show any $v(\mathrm{~S}-\mathrm{H})$ band at $2,570 \mathrm{~cm}^{-1}$, while the presence of $\mathrm{C}=\mathrm{S}$ stretching band at $1,252 \mathrm{~cm}^{-1}$ indicated that 5 exists in the thione form in the solid state $[42,43]$.

The ${ }^{1} \mathrm{H}-\mathrm{NMR}$ spectra of compound 3 , recorded in $\mathrm{CDCl}_{3}$, showed a singlet peak at $8.32 \mathrm{ppm}$ due to $\mathrm{N} H$ attached to a phenyl group while the other two singlets at $9.26 \mathrm{ppm}$ and 9.84 were attributed to the hydrazido group $\mathrm{NH}$ s. Both appear as a broad band which supports the formation of intramolecular 
hydrogen bonding [45,47] (Figure 3). The disappearance of the NH-1 and NH-2 groups of 3, combined with a singlet at $11.75 \mathrm{ppm}$ due to the presence of the NH-triazole of 5 suggest that a 1,2,4-triazole-5thione, and not a 1,2,4-triazole-5-thiol was formed.

Figure 3. Intramolecular hydrogen bonding of thioxo form of 1-acylthiosemicarbazide 3.

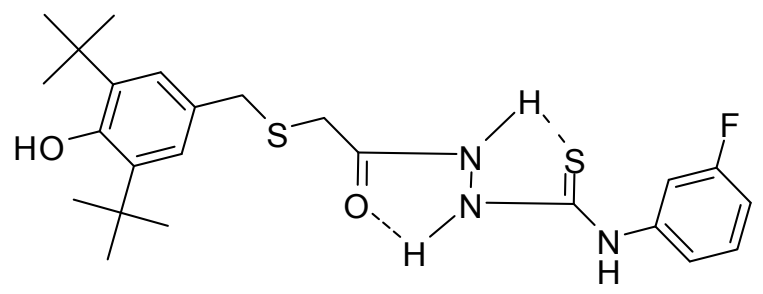

In the ${ }^{13} \mathrm{C}$-NMR spectra, the greatest differences between the acylthiosemicarbazide 3 and its cyclic derivatives 4 and 5 were found at the carbons designated C-8, C-9 and C-10. For C-8 in 3, this carbon was bonded to $\mathrm{C}-9(\mathrm{C}=\mathrm{O})$. The electron-withdrawing effects of the oxygen of the $\mathrm{C}=\mathrm{O}$ greatly deshielded the C-8 and caused it to appear at a high chemical shift of $33.76 \mathrm{ppm}$. After acid (base)-catalysed intramolecular dehydrative cyclizations of $\mathbf{3}$, the carbon at the same position (C-8) in 4 and $\mathbf{5}$ were bonded to the new C-9 due to the formation of thiadiazole and thiadiazole rings, respectively, so it had a new electronic environment. This greatly lowered the chemical shift of the methylene (C-8) to values of 29.96 and $24.68 \mathrm{ppm}$ in $\mathbf{4}$ and $\mathbf{5}$, respectively. Interestingly, the heteronuclear ${ }^{13} \mathrm{C}-{ }^{19} \mathrm{~F}$ coupling constants of compounds $\mathbf{3}, \mathbf{4}$ and $\mathbf{5}$ were 972, 984 and 1,004 Hz, respectively.

\subsection{Single Crystal X-ray Crystallography of Compounds $\mathbf{3}$ and $\mathbf{4}$}

The crystal structure of molecule 3 is depicted in Figure 4 and the selected bond lengths and angles are given in Table 1. In the crystal the molecule exists in its thione form. The two methylene carbon atoms, C15 and C16, subtend an angle of 100.77 (7) at S1 atom. Several atom pairs of the molecule are connected via N-H...O hydrogen bonding (Table 2) in a bifurcated system to form centro-symmetric dimers. The hydroxyl group is shielded by the two di-tert-butyl residues and therefore is not involved in any hydrogen bonding.

Figure 4. The molecular structures and labeling schemes of $\mathbf{3}$ (50\% probability ellipsoids).

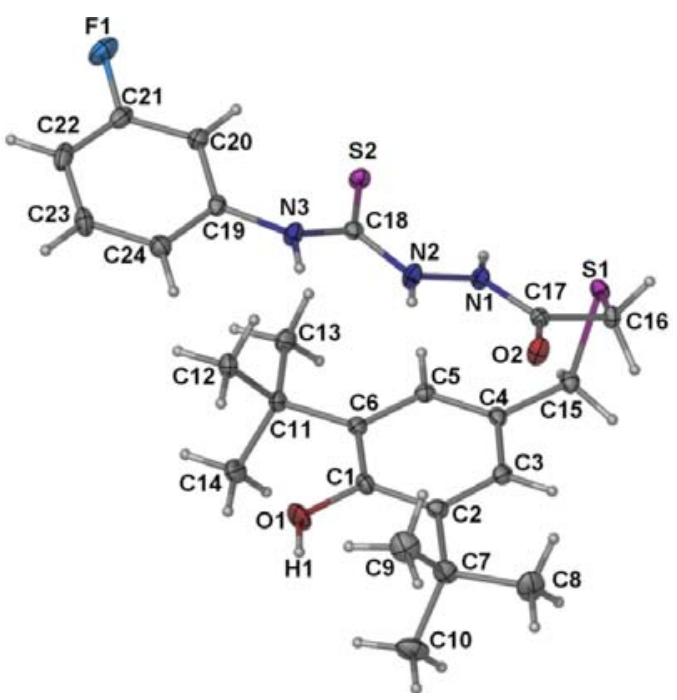


Table 1. Selected bond lengths $[\AA]$ and bond angles $\left[{ }^{\circ}\right]$ for 3 and 4.

\begin{tabular}{l|l|l|l}
\hline \multicolumn{5}{c}{3} & \multicolumn{2}{c}{ Bond lengths } \\
\hline $\mathrm{S}(2)-\mathrm{C}(18)$ & $1.6714(15)$ & $\mathrm{S}(2)-\mathrm{C}(17)$ & $1.728(6)$ \\
\hline $\mathrm{O}(2)-\mathrm{C}(17)$ & $1.2417(18)$ & $\mathrm{S}(2)-\mathrm{C}(18)$ & $1.749(6)$ \\
\hline $\mathrm{N}(1)-\mathrm{C}(17)$ & $1.3201(18)$ & $\mathrm{O}(1)-\mathrm{C}(1)$ & $1.376(6)$ \\
\hline $\mathrm{N}(1)-\mathrm{N}(2)$ & $1.3757(17)$ & $\mathrm{N}(1)-\mathrm{C}(17)$ & $1.293(7)$ \\
\hline $\mathrm{N}(2)-\mathrm{C}(18)$ & $1.3490(18)$ & $\mathrm{N}(1)-\mathrm{N}(2)$ & $1.395(6)$ \\
\hline $\mathrm{N}(3)-\mathrm{C}(18)$ & $1.3563(19)$ & $\mathrm{N}(2)-\mathrm{C}(18)$ & $1.296(6)$ \\
\hline $\mathrm{N}(3)-\mathrm{C}(19)$ & $1.4108(18)$ & $\mathrm{N}(3)-\mathrm{C}(18)$ & $1.365(7)$ \\
\hline \multicolumn{5}{c}{ Bond angles } \\
\hline $\mathrm{C}(16)-\mathrm{S}(1)-\mathrm{C}(15)$ & $100.77(7)$ & $\mathrm{C}(16)-\mathrm{S}(1)-\mathrm{C}(15)$ & $100.4(3)$ \\
\hline $\mathrm{C}(18)-\mathrm{N}(2)-\mathrm{N}(1)$ & $120.45(13)$ & $\mathrm{C}(18)-\mathrm{N}(3)-\mathrm{C}(19)$ & $130.8(5)$ \\
\hline $\mathrm{N}(2)-\mathrm{C}(18)-\mathrm{S}(2)$ & $121.18(11)$ & $\mathrm{C}(4)-\mathrm{C}(15)-\mathrm{S}(1)$ & $113.1(4)$ \\
\hline $\mathrm{N}(3)-\mathrm{C}(18)-\mathrm{S}(2)$ & $128.05(11)$ & $\mathrm{C}(17)-\mathrm{C}(16)-\mathrm{S}(1)$ & $112.1(4)$ \\
\hline
\end{tabular}

Table 2. Hydrogen-bond geometry for 3 and 4.

\begin{tabular}{|c|c|c|c|}
\hline 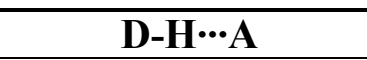 & $\mathbf{H} \cdots \mathbf{A}[\AA]$ & $\mathbf{D} \cdots \mathbf{A}[\AA]$ & 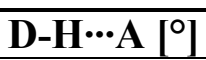 \\
\hline \multicolumn{4}{|c|}{3} \\
\hline $\mathrm{N}(3)-\mathrm{H}(3 \mathrm{~N}) \ldots \mathrm{O}(2)^{\# \mathrm{I}}$ & $2.040(15)$ & $2.8570(16)$ & $158.1(17)$ \\
\hline $\mathrm{N}(2)-\mathrm{H}(2 \mathrm{~N}) \ldots \mathrm{O}(2)$ & $2.019(16)$ & $2.7927(17)$ & $150.4(17)$ \\
\hline \multicolumn{4}{|c|}{4} \\
\hline $\mathrm{N}(3)-\mathrm{H}(3 \mathrm{~N}) \ldots \mathrm{N}(2){ }^{\# 2}$ & $2.05(2)$ & $2.910(7)$ & $169(5)$ \\
\hline
\end{tabular}

Figure 5 presents the molecular structure of compound 4 and Table 1 compiles the selected bond lengths and angles. The thiadiazole ring makes dihedral angles of $14.6(3)^{\circ}$ and $29.6(2)^{\circ}$ with the $\mathrm{C} 10-\mathrm{C} 24$ and C1-C6 aromatic rings, respectively. Similar to what was observed in the structure of the semicarbazide 3, the hydroxyl group is not involved in any hydrogen bonding as it is shielded by the two sterically hindered tert-butyl groups. In the crystal, pairs of N3-H...N2 hydrogen bonds (Table 2) link the molecules into centro-symmetric dimers.

Figure 5. The molecular structure and labeling scheme of 4 (50\% probability ellipsoids).

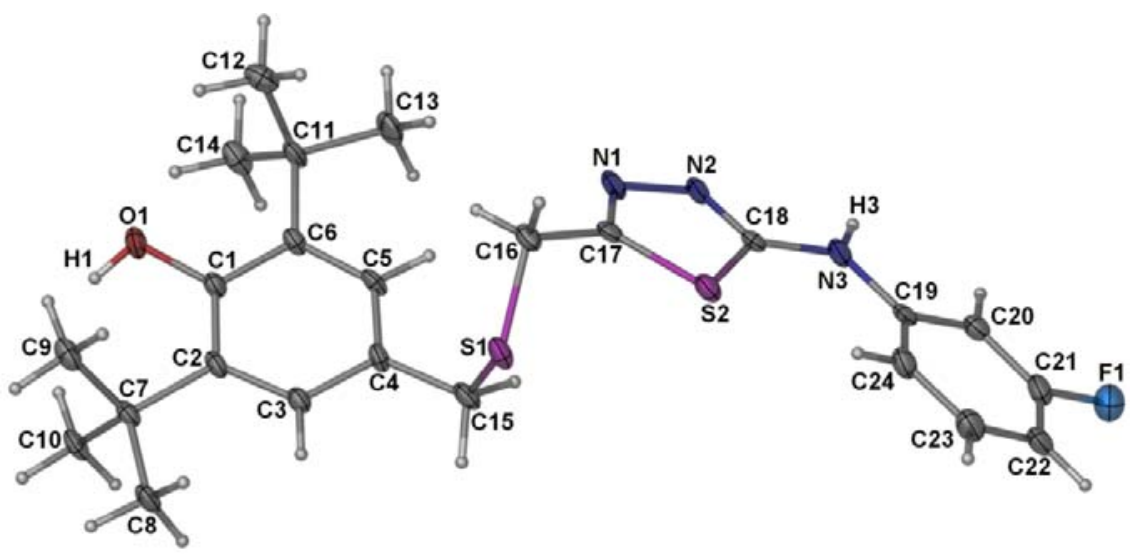

The crystal data and structure refinement for compounds $\mathbf{3}$ and $\mathbf{4}$ is summarized in Table 3. 
Table 3. Crystal data and refinement parameters for 3 and $\mathbf{4}$.

\begin{tabular}{lll}
\hline & $\mathbf{3}$ & $\mathbf{4}$ \\
\hline Empirical formula & $\mathrm{C}_{24} \mathrm{H}_{32} \mathrm{~F} \mathrm{~N}_{3} \mathrm{O}_{2} \mathrm{~S}_{2}$ & $\mathrm{C}_{24} \mathrm{H}_{30} \mathrm{~F} \mathrm{~N}_{3} \mathrm{O} \mathrm{S}_{2}$ \\
Formula weight & 477.65 & 459.63 \\
Crystal system & Triclinic & Monoclinic \\
Space group & $P-1$ & $C 2 / \mathrm{c}$ \\
Unit cell dimensions & & \\
$a[\AA]$ & $9.3441(5)$ & $28.911(11)$ \\
$b[\AA]$ & $11.1548(6)$ & $5.731(2)$ \\
$c\left[^{\AA}\right]$ & $11.7683(6)$ & $28.430(11)$ \\
$\alpha\left[^{\circ}\right]$ & $91.189(2)$ & \\
$\beta\left[^{\circ}\right]$ & $93.388(2)$ & $99.330(5)$ \\
$\gamma\left[^{\circ}\right]$ & $93.224(2)$ & \\
Volume $\left[\AA^{3}\right]$ & $1,222.19(11)$ & $4,648(3)$ \\
$Z$ & 2 & 8 \\
Independent reflections & $5,587\left[R_{\text {int }}=0.0428\right]$ & $4,202\left[R_{\text {int }}=0.2119\right]$ \\
Observed reflections $[I>2 \sigma(I)]$ & 4,988 & 1,848 \\
Final $R$ indices $[I>2 \sigma(I)]$ & $R_{1}=0.0405, w R_{2}=0.1135$ & $R_{1}=0.0690, w R_{2}=0.1340$ \\
$R$ indices (all data) & $R_{1}=0.0448, w R_{2}=0.1160$ & $R_{1}=0.1792, w R_{2}=0.1820$ \\
\hline
\end{tabular}

\subsection{Computational Evaluation of Biological Activity}

The biological activity spectra of the target compounds were obtained using the Prediction of Activity Spectra for Substances (PASS) software [48]. PASS prediction tools are constructed using 20,000 principal compounds from the MDDR database (produced by Accelrys and Prous Science) [49]. The database contains over 180,000 biologically relevant compounds and is constantly updated [49]. PASS web tool has the ability to predict about 4,000 kinds of biological activity on the basis of structural formula with mean accuracy of about 90\% [50,51], therefore, it is reasonable to use PASS for finding and optimizing new lead compounds. The PASS training set which has been compiled from various sources including publications, patents, chemical databases, and "gray" literatures consists of over 26,000 biological compounds and includes drugs, lead compounds, drug-candidates, and toxic substances. Algorithm of activity spectrum estimation is based on Bayesian approach. The result of prediction is presented as the list of activities with appropriate $\mathrm{Pa}$ and $\mathrm{Pi}$ ratio. $\mathrm{Pa}$ and $\mathrm{Pi}$ are the estimates of probability for the compound to be active and inactive respectively for each type of activity from the biological. It is reasonable that only those types of activities may be revealed by the compound, which $\mathrm{Pa}>\mathrm{Pi}$. If $\mathrm{Pa}>0.3$ the compound is likely to reveal this activity in experiments, but in this case the chance of being the analogue of the known pharmaceutical agents for this compound is also high. A portion of the predicted biological activity spectra (lipid peroxidase inhibitor, antioxidant, free radical scavenger and antiinflammatory) for the synthesized compounds and BHT are given in Table 4. 
Table 4. Part of the predicted biological activity spectra for the compounds $\mathbf{1}, \mathbf{3}-\mathbf{5}$ and BHT.

\begin{tabular}{|l|c|c|c|c|c|c|c|c|c|c|}
\hline \multirow{2}{*}{$\begin{array}{l}\text { Mode of } \\
\text { biological activity }\end{array}$} & \multicolumn{2}{|c|}{$\mathbf{1}$} & \multicolumn{2}{|c|}{$\mathbf{3}$} & \multicolumn{2}{|c|}{$\mathbf{4}$} & \multicolumn{2}{|c|}{$\mathbf{5}$} & \multicolumn{2}{c|}{ BHT } \\
\cline { 2 - 11 } & $\mathrm{Pa}$ & $\mathrm{Pi}$ & $\mathrm{Pa}$ & $\mathrm{Pi}$ & $\mathrm{Pa}$ & $\mathrm{Pi}$ & $\mathrm{Pa}$ & $\mathrm{Pi}$ & $\mathrm{pa}$ & $\mathrm{Pi}$ \\
\hline $\begin{array}{l}\text { Lipid peroxidase } \\
\text { inhibitor }\end{array}$ & 0.652 & 0.006 & 0.436 & 0.027 & 0.485 & 0.019 & 0.639 & 0.007 & 0.843 & 0.003 \\
\hline Antioxidant & 0.712 & 0.004 & 0.385 & 0.035 & 0.420 & 0.028 & 0.529 & 0.015 & 0.845 & 0.003 \\
\hline $\begin{array}{l}\text { Free radical } \\
\text { scavenger }\end{array}$ & 0.807 & 0.004 & 0.585 & 0.025 & 0.554 & 0.031 & 0.506 & 0.042 & 0.797 & 0.004 \\
\hline Antiinflammatory & 0.659 & 0.017 & 0.375 & 0.136 & 0.649 & 0.018 & 0.479 & 0.065 & 0.804 & 0.005 \\
\hline
\end{tabular}

$\mathrm{Pa}$ - probability "to be active"; $\mathrm{Pi}$ - probability "to be inactive".

\subsection{Molecular Properties and Drug-Likeness}

\subsubsection{Calculation of Drug-Likeness Properties}

Drug-likeness can be defined as a delicate balance between various structural features, which determine whether a particular molecule is similar to recognized drugs. It generally means molecules, which contain functional groups and/or have physical properties consistent with most of the known drugs. These properties are; absorption, distribution, metabolism, and excretion in the human body like a drug. Lipinski [52] used these molecular properties in formulating his Rule of Five. The rule states that the most molecules with good membrane permeability have $\log P<5$, molecular weight $<500$, number of hydrogen bond acceptors $<10$, number of hydrogen bond donors $<5$. Number of rotatable bonds is important for conformational changes of molecules under study and ultimately for the binding with receptors or channels [53]. It is revealed that for passing oral bioavailability criteria, number of rotatable bond should be $(\leq 10)$. The synthesized compounds $\mathbf{1}$ and $\mathbf{3}-\mathbf{5}$ in general possessed high number of rotatable bonds (6-10) and therefore, obviously exhibit large conformational flexibility.

\subsubsection{Lipophilicity}

Generally, lipophilic antioxidants demonstrated more potent scavenging properties than hydrophilic antioxidants. Vitamin E is a fat-soluble antioxidant [54]. Distribution of this vitamin within the membrane has been shown to alter its antioxidant potency [55]. The Partition Coefficient is a measure of how well a substance partitions between a lipid and water. It is therefore important to determine these physico-chemical properties associated with an antioxidant activity. $\log P$ measurements $(P$ is partition coefficient of the molecule in the water-octanol system) are a useful parameter for use in understanding the behaviour of antioxidant molecules. For calculation of $\log P$, we used computed $\log P$ values by using ADMET predictive software as shown in Table 5 . Compounds having $\log P \geq 5$ should be considered as a higher lipophilicity have higher permeation across biological membranes (but lower aqueous solubility) [56]. The $\log P$ values showed that the order of lipophilicity was 1-acyl-semicarbazide $\mathbf{3}<$ triazole 5 (thione form) $<$ thiadiazole 4 and 5 (thiol form). Compounds 3-5 showed lipophilic properties with $\log P$ values between 6.439-6.967 while natural lipophilic antioxidant, $\alpha$-tocopherol $(\alpha-\mathrm{TOH})(10.44)$ and, hydrophilic antioxidant, ascorbic acid $(-1.70)$. 
Table 5. Predicted ADMET and Lipinski's parameters.

\begin{tabular}{|c|c|c|c|c|c|c|c|c|}
\hline Compound & $\begin{array}{c}\text { Violation of } \\
\text { Rule of } 5(\leq 1)\end{array}$ & $\begin{array}{l}\text { HBA } \\
(\leq 10)\end{array}$ & $\begin{array}{c}\text { HBD } \\
(\leq 5)\end{array}$ & $\begin{array}{c}\log P \\
(\leq 5)\end{array}$ & $\begin{array}{c}\text { MW } \\
(\leq \mathbf{5 0 0})\end{array}$ & $\begin{array}{l}\text { NROTB } \\
(\leq 10)\end{array}$ & $\% A B S$ & $\begin{array}{c}\text { PSA } A^{2} \\
\leq 90\end{array}$ \\
\hline 1 & 0 & 4 & 2 & 4.41 & 310.452 & 6 & 88.66 & 58.93 \\
\hline 3 & 1 & 4 & 4 & 6.43 & 477.658 & 10 & 82.59 & 76.54 \\
\hline 4 & 1 & 5 & 2 & 6.94 & 459.643 & 8 & 89.63 & 56.14 \\
\hline 5 (thione) & 1 & 4 & 2 & 6.84 & 459.643 & 7 & 92.33 & 48.30 \\
\hline 5 (thiol) & & 5 & 2 & 6.96 & 459.643 & 7 & 92.21 & 48.68 \\
\hline BHT & 0 & 1 & 1 & 4.87 & 220.350 & 2 & 101.81 & 20.81 \\
\hline Vitamin $\mathbf{E} *$ & - & - & - & 10.44 & 430.71 & - & 98.73 & 29.74 \\
\hline Vitamin $\mathbf{C} *$ & - & - & - & -1.70 & 176.12 & - & 71.23 & 109.49 \\
\hline
\end{tabular}

* Vitamin E and C are outside the "rule of 5" [52], BHT-butylated hydroxytoluene, HBA — hydrogen bond acceptor, HBD—hydrogen bond donor, NROTB — number of rotated bonds, PSA - polar surface area.

\subsubsection{Violations of Lipinski’s Rule of Five}

It is very important to note that there are many violations of this rule among currently existing drugs and vice versa, but in general, an orally active drug has no more than one violation. Compounds violating more than one of the Lipinski Rules are reasonably assumed to have bioavailability problems and are therefore, presumably unsuitable as drugs [57]. However, qualifying the RO5 does not absolute guarantee that a molecule is "drug-like" [58]. Moreover, the RO5 says nothing about specific chemistry structural features found in drugs or non-drugs [59]. Polar surface area (PSA) is basically recognized as a good indicator of drug absorbance in the intestines, Caco-2 monolayers penetration, and blood-brain barrier crossing [58].

The earlier mentioned parameters were calculated for the BHT derivatives in analysis, and the results are depicted in Table 4. From the data obtained, one can notice that the synthesized compounds possess an adequate number of proton acceptor and proton donor groups to ensure efficient interaction with the hydrogen-bonding groups of the receptors. Hydrogen-bonding capacity has been also identified as an important parameter for describing drug permeability [60]. All the BHT derivatives were found to violate one of the Lipinski's parameters $(\log P \leq 5)$, although they have been found to have solubility in protic solvents. Magnitude of absorption is expressed by the percentage of absorption; Absorption percent was calculated [61] using the equation: \% ABS $=109-(0.345 \times \mathrm{PSA})$. Accordingly, to their predictive low PSA (PSA values are considerably less than $90 \mathrm{~A}^{2}$ ) and high \% ABS data it seems that this type of antioxidants could have a good capacity for penetrating cell membranes [53].

\subsection{In Vitro Antioxidant Activities}

In present study, antioxidant activities of five BHT derivatives were carried out by two well known in vitro antioxidant assays, DPPH and TBARS. The effects of antioxidants in the DPPH-radicalscavenging test reflects the hydrogen-donating capacity of a compound. In its radical form, DPPH• absorbs at $570 \mathrm{~nm}$. The radical form of DPPH is scavenged by an antioxidant through the donation of a 
hydrogen atom to form a stable DPPH molecule. This leads to a colour change from purple to yellow, and a corresponding decrease in absorbance $[62,63]$.

The thiobarbituric acid reactive substances (TBARS) assay is used for screening and monitoring lipid peroxidation. The basis of TBARS assay is the absorbance of a pink coloured complex that is monitored spectrophotometrically at 532-535 $\mathrm{nm}$ which is formed between thiobarbituric acid and the oxidation products of unsaturated lipids $[64,65]$.

\subsubsection{In Vitro DPPH Free Radical Scavenging Activity}

Compound 3 showed significant levels of \% inhibition of DPPH radical compared to the standard antioxidant (BHT) used in the study (Table 6). As shown in this Table, thiosemicarbazide 3 exhibited strong scavengings effect on DPPH stable radical, with an $\mathrm{IC}_{50}$ value of $68.03 \pm 1.27 \mu \mathrm{M} / \mathrm{mL}$.

Table 6. $\mathrm{IC}_{50}$ value and \% inhibition of the DPPH radical scavenging and lipid peroxidation inhibition assays.

\begin{tabular}{|c|c|c|}
\hline \multirow{2}{*}{ Compounds } & \multicolumn{2}{|c|}{$\mathrm{IC}_{50}{ }^{\mathrm{a}}$ Values $(\mu \mathrm{M} / \mathrm{mL}) \pm$ S.E.M ${ }^{\mathrm{b}}$ and Max. inhibition $\% \pm$ S.E.M } \\
\hline & DPPH Radical Scavenging & Lipid Peroxidation Inhibition \\
\hline 1 & $96.73 \pm 1.87(51.25 \pm 0.82)$ & $38.84 \pm 1.54(73.99 \pm 1.30)$ \\
\hline 3 & $68.03 \pm 1.27(65.21 \pm 0.55)$ & $56.00 \pm 5.05(74.64 \pm 1.68)$ \\
\hline 4 & $>100^{\mathrm{c}}(26.09 \pm 0.33)$ & $33.20 \pm 2.91(84.99 \pm 1.37)$ \\
\hline 5 & $85.30 \pm 1.16(65.26 \pm 0.38)$ & $16.07 \pm 3.51(83.99 \pm 1.65)$ \\
\hline BHT & $>100^{\mathrm{c}}(25.23 \pm 0.17)$ & $36.67 \pm 1.78(79.45 \pm 1.27)$ \\
\hline Ascorbic acid & $67.77 \pm 0.17(71.93 \pm 1.61)$ & - \\
\hline$\alpha-$ TOH & - & $5.63 \pm 1.09(84.69 \pm 1.23)$ \\
\hline
\end{tabular}

${ }^{\mathrm{a}}$ IC50: $50 \%$ effective concentration; ${ }^{\mathrm{b}}$ S.E.M: standard error of the mean; ${ }^{\mathrm{c}}$ did not reach $50 \%$ inhibition.

This value was lower than that of the thiadiazole 4, triazole 5, BHT and quite close to that of ascorbic acid $(67.77 \pm 0.17 \mu \mathrm{M} / \mathrm{mL})$, which was used as a positive control in the study, clearly indicating that thiosemicarbazide $\mathbf{3}$ has good radical scavenging activity. Presumably, significantly greater inhibition of lipid peroxidation could be attributed to the phenylthiourea system which is the active center of antioxidation, acts as the active center of containing thione and secondary aromatic amine antioxidants (Figure 6).

Figure 6. Phenylthiourea system.

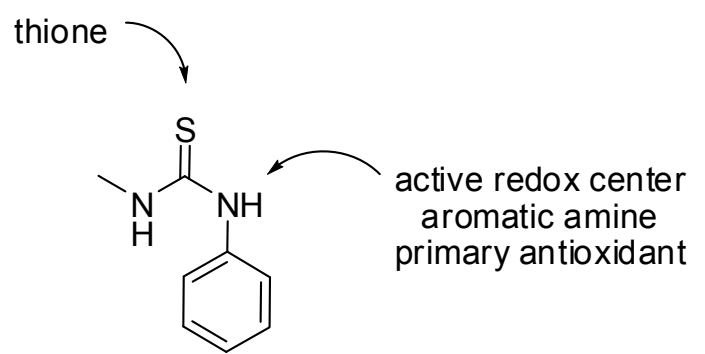

This result is in agreement with previous reports whereby thiourea compounds exhibited antioxidant activity, while $S$-alkylation virtually eliminated the antioxidant activity, which indicated 
that an unalkylated thiourea group is critical to antioxidant activity. In addition, according to the published report, thiosemicarbazide obviously showed greater antioxidant property than triazole and thiadiazole [66]. The X-ray structures (Figure 4) and also the ${ }^{1} \mathrm{H}-\mathrm{NMR}$ data of 3 revealed that the thione form is formed. Thus, the DPPH inhibition result of compound $\mathbf{3}$ suggested that the thione form is largely responsible for the antioxidant activity due to its favourable electron-donating characteristics.

In addition to that, the active redox center of compound 3 is the Ar- $\mathbf{N H}$ - (Figure 6) which increases the rate of $\mathrm{H}$-atom transfer to neutralize the $\mathrm{DPPH} \bullet$ by delocalization of the nitrogen electron pair over the aromatic system and the thione group, forming a stable aminyl radical, thus yielding a DPPH• inhibition of $65.21 \%$ for 3 , while ascorbic acid and BHT gave values of $71.93 \%$ and $25.23 \%$, respectively.

Compound 4 did not show any DPPH radical-scavenging activity compared to BHT and $\mathbf{1}$. This could be attributed to the fact that the electron-withdrawing groups produce a strengthening of the N-H bond. This behavior can be attributed to the conjugative effect of the substituents $[67,68]$.

Table 6 clearly shown the \% inhibition of compound 5 to be higher than BHT and close to that of ascorbic acid. Presumably, like 4, the 1,2,4-triazole is present in the thione form as a planar molecule. The increased stability of the thione form (I) over thiol form (II) (Scheme 2) has been shown theoretically, and the sulfur atom is found to be the atom with largest electron density in the molecule [69]. Thus, the chemical behaviour of the system with respect to free radicals would largely depend on the tautomeric form present in the reaction, reasonably assuming that the sulfur atom is involved in the reactive site.

Scheme 2. Thione I and thiol II tautomers of 5.

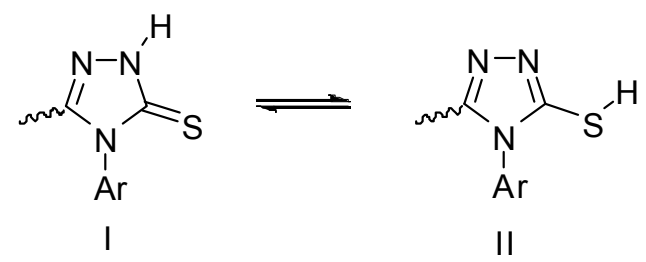

Although we don't have an exact explanation for the greater activity of 5, we have some logical arguments. Heterocyclic systems with halogen substituents have shown greater antioxidant properties than other substituents [40,41]. Takanori et al. [70] studied the antioxidant activity of $o$-benzyl-substituted phenols and found that electron-withdrawing groups on benzyl substituent decreases the electron density of methylene, making hydrogen transfer to a phenoxy radical easier and regenerated the antioxidant activity of phenols. Thus, the fluorine group in compound $\mathbf{5}$ seemed to enhance free radical scavenging by making the $\mathrm{NH}$ of triazole ring easy to regenerate reversibly recycling antioxidant activity [71] or this might be due to its electron-donating mesomeric effect [39].

\subsubsection{In Vitro Lipid Peroxidation Activity}

Contrary to the DPPH assay results, compound $\mathbf{3}$ exhibited the lowest lipid peroxidation activity yielding the highest $\mathrm{IC}_{50}$ value of $56 \pm 5.05 \mu \mathrm{M} / \mathrm{mL}$. Compound 4 was higher than BHT, with an $\mathrm{IC}_{50}$ value of $33.20 \pm 2.91 \mu \mathrm{M} / \mathrm{mL}$. Interestingly, thiadiazole $\mathbf{5}$ exhibited the strongest inhibitory activity with $\mathrm{IC}_{50} 16.07 \pm 3.51 \mu \mathrm{M} / \mathrm{mL}$ (inhibition $=83.99 \%$ ) which is two times better than the $\mathrm{IC}_{50}$ of the standard antioxidant $\mathrm{BHT}$ with $\mathrm{IC}_{50}=36.67 \pm 1.1 .78 \mu \mathrm{M} / \mathrm{mL}$ and close to that of vitamin $\mathrm{E}$ 
$\left(\mathrm{IC}_{50}=5.63 \pm 1.09 \mu \mathrm{M} / \mathrm{mL}, \%\right.$ inhibition $\left.=84.69\right)$. It is known that $\alpha-\mathrm{TOH}$ and BHT are strongly lipophilic antioxidants due to their long hydrocarbon chain and di-tert-butyl groups similar to the tail of a fatty acid and therefore, reach a higher level of bioavailability [72]. Presumably, the significantly greater differences between the lipid peroxidation values of $\mathbf{3}, 4$ and 5 could be attributed to the balance between the hydrophilicity of the polar moieties and the lipophilicity of the hydrocarbon moieties. Thus, the stronger inhibitory activity of compound $\mathbf{5}$ could be attributed to hydrophilic and also lipophilic effects on emulsified oils. In emulsions, which is the medium of the TBARS assay, non-polar free radical scavengers accumulate in the lipid phase and at the oil-water interface where interactions between hydroperoxides at the droplet surface and prooxidants in the aqueous phase occur [73-75].

Structurally, in 2010 Imtiaz et al. [76] found triazole derivatives to be relatively more active than the derivatives of thiadiazole. These may be regarded as substrate-like inhibitors on the basis of their structural similarity with the natural substrate of urease (i.e., urea). Similarly, hydroxyphenylurea derivatives exhibit 10 times higher antioxidant activity than $\alpha$-TOH [24]. Thus, results of lipid peroxidation inhibition of compound 5 suggested that a 1,2,4-triazole bearing a BHT moiety and $m$-flourophenyl can donate electron/hydrogen easily. However, the $m$-flouro substituent could also enhance the antioxidant activity of BHT similar to donating groups, which could be attributed to its electron-donating mesomeric effect [41] but not to the conjugative effect [67,68], and maybe to intermolecular lipophilicity effects [77].

$\log P$ calculations of 4 and 5 (Table 5) showed the thione form of $5(\log P=6.84$ ) to have only slight more polarity than $4(\log P=6.94)$ due to thiol-thione tautomerism effect, which suggested compound $\mathbf{4}$ and 5 to have hydrophilic and lipophilic groups, which may act as amphiphilic antioxidants in one molecule rather than having to use two antioxidants separately. Thus, results of lipid peroxidation inhibition of compound $\mathbf{5}$ suggested that it to be possible candidate with promising anti-oxidant activities.

\section{Experimental}

\subsection{General}

All materials and solvents were obtained from Sigma-Aldrich. Melting points were determined on a MEL-TEMP II melting point instrument. IR spectra were recorded on a Perkin-Elmer RX1 FT-IR spectrometer. The ${ }^{1} \mathrm{H}-(400 \mathrm{MHz})$ and ${ }^{13} \mathrm{C}-\mathrm{NMR}(100 \mathrm{MHz})$ spectra were recorded on JEOL ECA $400 \mathrm{MHz}$ FT-NMR using $\mathrm{CDCl}_{3}$ or DMSO- $d_{6}$ as solvent and tetramethylsilane as an internal standard. HR-mass spectra (ESI) were obtained with a MAT 95 xl-T mass spectrometer operating at $70 \mathrm{ev}$. UV-visible spectra were recorded on a UV-1650PC model UV-visible spectrophotometer.

\section{2-(2-(3,5-di-tert-Butyl-4-hydroxybenzylthio)acetyl)-N-(3-luorophenyl)hydrazinecarbothioamide}

To a solution of $S$-(3,5-di-t-butyl-4-hydroxybenzyl)thioglycolic acid hydrazide (2, $0.45 \mathrm{~g}, 1.39 \mathrm{mmol})$ in dry toluene or benzene $(5 \mathrm{~mL})$, was added 3-fluorophenylisothiocyanate $(0.21 \mathrm{~g}, 1.39 \mathrm{mmol})$ and the reaction mixture was stirred for $2 \mathrm{~h}$ at room temperature. The resulting precipitate was collected by filtration, washed with boiled hexane, dried at room temperature, and recrystallized from toluene to give white solid, yield 92\% (0.60 g), mp 180-182 ${ }^{\circ} \mathrm{C}$. IR ( $\mathrm{KBr}$ pellet), $\mathrm{cm}^{-1}: v=3,633$ (free $\mathrm{OH}$, BHP), 3,340, 3,314 and 3,285 (NH), 2,873-2,961 (C-H of $t$-Bu), 1,713 (C=O), 1,248 v (C=S). ${ }^{1} \mathrm{H}-\mathrm{NMR}$ 
$\left(\mathrm{CDCl}_{3}\right), \delta$, ppm: $1.40(\mathrm{~s}, 18 \mathrm{H}, 2 \times t-\mathrm{Bu}), 3.22(\mathrm{~s}, 2 \mathrm{H}, \mathrm{H}-8), 3.78(\mathrm{~s}, 2 \mathrm{H}, \mathrm{H}-7), 5.20(\mathrm{~s}, 1 \mathrm{H}, \mathrm{OH}, \mathrm{BHP})$, $6.62-6.66\left(\mathrm{dt}, 1 \mathrm{H}, \mathrm{H}-14,{ }^{3} J_{F-H}=8.2,{ }^{3} J=8,{ }^{4} \mathrm{~J}=2.3 \mathrm{~Hz}\right.$ ), 6.85-6.87 (d, $\left.1 \mathrm{H}, \mathrm{H}-16,{ }^{3} \mathrm{~J}=8 \mathrm{~Hz}\right), 7.04-7.10$ (m, 1H, H-15), 7.10 (2H, H-3, H-5), 7.20-7.25 (m, 1H, H-12), 7.97 (b, 2H, NH-2, NH-3), 8.90 (1H, $\mathrm{NH}-1) .{ }^{13} \mathrm{C}-\mathrm{NMR}\left(\mathrm{CDCl}_{3}\right), \delta$, ppm: $30.30\left(6 \mathrm{C}, 2 \times-\mathrm{C}\left(\mathrm{CH}_{3}\right)_{3}, 33.51(1 \mathrm{C}, \mathrm{C}-8), 34.41\left(2 \mathrm{C}, 2 \times-\mathrm{C}\left(\mathrm{CH}_{3}\right)_{3}\right)\right.$, $37.48(1 \mathrm{C}, \mathrm{C}-7), 106.65\left(\mathrm{~d}, 1 \mathrm{C}, \mathrm{C}-12,{ }^{2} J_{\mathrm{C}-F}=104 \mathrm{~Hz}\right), 110.01\left(\mathrm{~d}, 1 \mathrm{C}, \mathrm{C}-14,{ }^{2} J_{C-F}=88 \mathrm{~Hz}\right), 114.52$ (1C, C-16), 125.89 (2C, C-3, C-5), 126.93 (1C, C-4), 129.94 (d, 1C, C-15, $\left.{ }^{3} J_{C-F}=36 \mathrm{~Hz}\right), 136.41(2 \mathrm{C}$, C-2, C-6), 139.60 (d, 1C, C-11, ${ }^{3} J_{C-F}=44$ Hz), 153.35 (1C, C-1), 154.55 (1C, C-10), 163.02 (d, 1C, C-13, ${ }^{1} J_{C-F}=972 \mathrm{~Hz}$ ), 170.13(1C, C-9). HREIMS $m / z 477.1918[\mathrm{M}]^{+}$(calcd for $\mathrm{C}_{24} \mathrm{H}_{32} \mathrm{O}_{2} \mathrm{~N}_{3}$ FS 477.1920).
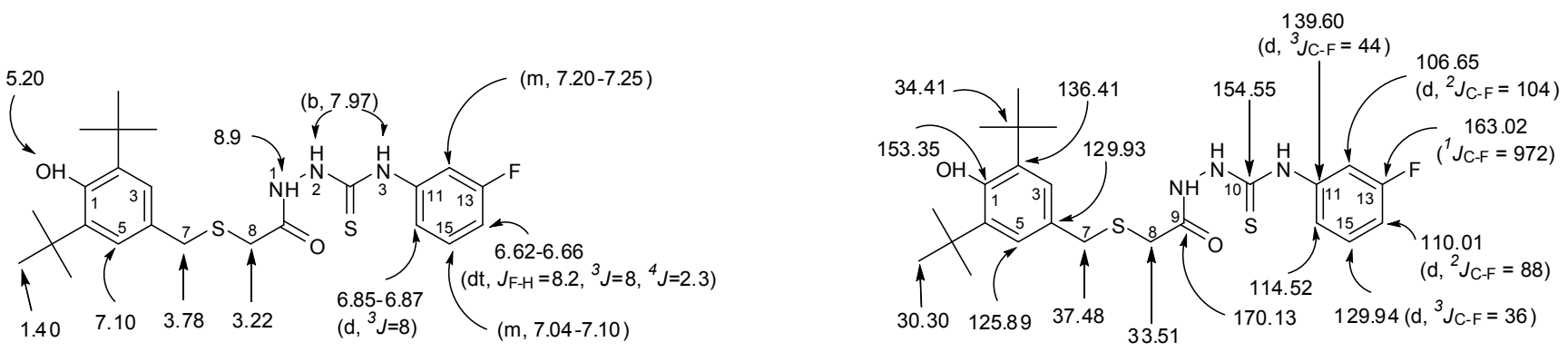

2,6-di-tert-Butyl-4-(((5-(3-fluorophenylamino)-1,3,4-thiadiazol-2-yl)methylthio)methyl)phenol

Thiosemicarbazide $3(0.23 \mathrm{~g}, 0.48 \mathrm{mmol})$ was added gradually under stirring to a cooled sulphuric acid solution $(50 \%, 5 \mathrm{~mL})$ for $10 \mathrm{~min}$. The reaction mixture was heated for $20 \mathrm{~min}$ at $100{ }^{\circ} \mathrm{C}$. It was then poured over crushed ice under stirring. The solid precipitated was filtered, washed with water, dried and recrystallized from $\mathrm{MeOH} 4: 1 \mathrm{H}_{2} \mathrm{O}$, white solid, Yield $60 \%(0.13 \mathrm{~g}) . \mathrm{mp} 175-177{ }^{\circ} \mathrm{C}$. IR $(\mathrm{KBr}$ pellet), $\mathrm{cm}^{-1}: v=3,623,3,631,3,653$ (free $\mathrm{OH}, \mathrm{BHP}$ ), 2,873-2,958 (C-H of $t$-Bu), 1,616, 1,610 $(2 \mathrm{C}=\mathrm{N}) .{ }^{1} \mathrm{H}-\mathrm{NMR}\left(\mathrm{CDCl}_{3}\right), \delta$, ppm: $1.40(\mathrm{~s}, 18 \mathrm{H}, 2 \times t$-Bu), 3.69 (s, 2H, H-7), 3.89 (s, 2H, H-8), 5.12 (s, 1H, OH, BHP), 6.76-6.81 (ddt, 1H, H-14, $\left.{ }^{3} J_{F-H}=8.5,{ }^{3} J=8.4,{ }^{4} J=0.8 \mathrm{~Hz}\right), 7.07$ (2H, H-3, H-5), $7.09-7.12\left(\mathrm{dd}, 1 \mathrm{H}, \mathrm{H}-16,{ }^{3} J=8.2,{ }^{4} \mathrm{~J}=0.92 \mathrm{~Hz}\right), 7.14-7.18\left(\mathrm{dt}, 1 \mathrm{H}, \mathrm{H}-12,{ }^{3} J_{F-H}=10.4,{ }^{4} J=2.7\right.$, $\left.{ }^{4} J=2.4 \mathrm{~Hz}\right), 7.27-7.33\left(\mathrm{dt}, 1 \mathrm{H}, \mathrm{H}-15,{ }^{3} J=8.5,{ }^{3} \mathrm{~J}=8 \mathrm{~Hz}\right), 8-9(\mathrm{~b}, \mathrm{NH}) .{ }^{13} \mathrm{C}-\mathrm{NMR}\left(\mathrm{CDCl}_{3}\right), \delta, \mathrm{ppm}:$ $29.96(1 \mathrm{C}, \mathrm{C}-8), 30.33\left(6 \mathrm{C}, 2 \times-\mathrm{C}\left(\mathrm{CH}_{3}\right)_{3}\right), 34.40\left(2 \mathrm{C}, 2 \times-\mathrm{C}\left(\mathrm{CH}_{3}\right)_{3}\right), 36.62(1 \mathrm{C}, \mathrm{C}-7), 112.20(\mathrm{~d}, 1 \mathrm{C}$, $\left.\mathrm{C}-12,{ }^{2} J_{\mathrm{C}-\mathrm{F}}=103 \mathrm{~Hz}\right), 110.3\left(\mathrm{~d}, 1 \mathrm{C}, \mathrm{C}-14,{ }^{2} J_{\mathrm{C}-\mathrm{F}}=88 \mathrm{~Hz}\right), 113.62\left(1 \mathrm{C}, \mathrm{C}-16,{ }^{4} J_{\mathrm{C}-\mathrm{F}}=11.2 \mathrm{~Hz}\right), 125.97$ (2C, C-3, C-5), 127.50 (1C, C-4), 130.96 (d, 1C, C-15, $\left.{ }^{3} J_{C-F}=38.4 \mathrm{~Hz}\right), 136.18(2 \mathrm{C}, \mathrm{C}-2, \mathrm{C}-6), 141.73$ $\left(\mathrm{d}, 1 \mathrm{C}, \mathrm{C}-11,{ }^{3} J_{\mathrm{C}-F}=42 \mathrm{~Hz}\right), 153.18(1 \mathrm{C}, C-1), 160.17$ (1C, C-9), 163.54 (d, 1C, C-13, ${ }^{1} J_{C-F}=984 \mathrm{~Hz}$ ), 166.59 (1C, C-10). HREIMS $m / z 459.1759[\mathrm{M}]^{+}$(calcd for $\mathrm{C}_{24} \mathrm{H}_{30} \mathrm{O}_{1} \mathrm{~N}_{3} \mathrm{FS}_{2} 459.1814$ ).
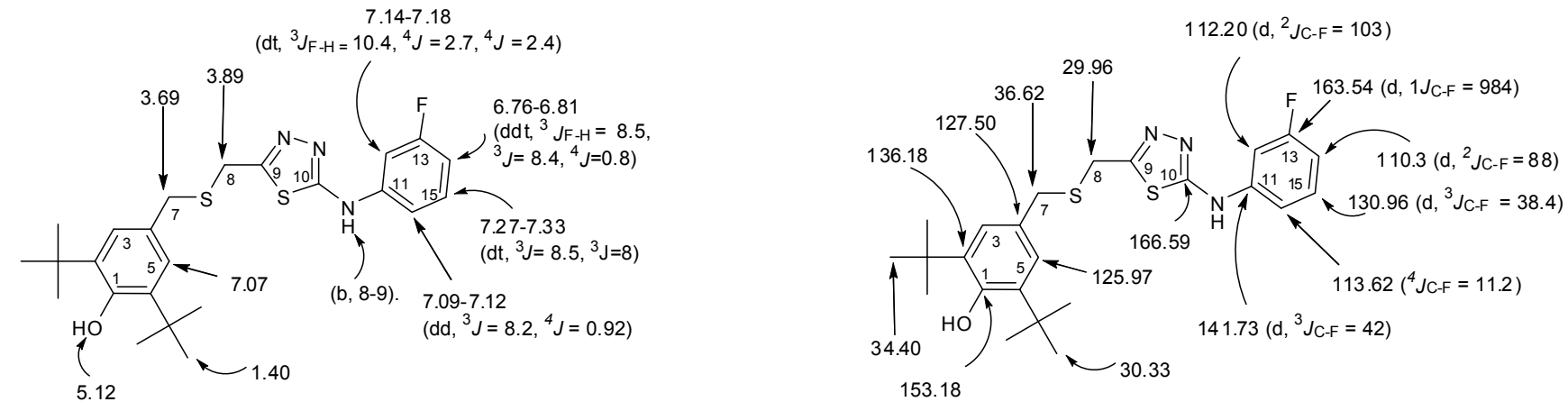
3-((3,5-di-tert-Butyl-4-hydroxybenzylthio)methyl)-4-(3-fluorophenyl)-1H-1,2,4-triazole-5(4H)-thione (5). A mixture of thiosemicarbazide $3(0.23 \mathrm{~g}, 0.48 \mathrm{mmol})$ and potassium carbonate $(25 \%, 5 \mathrm{~L})$ was stirred for $18 \mathrm{~h}$. Water $(250 \mathrm{~mL})$ was added and the solution was stirred for $1 \mathrm{~h}$, the solution was adjusted to pH 5-6 with dilute hydrochloric acid and was kept aside for $1 \mathrm{~h}$. The resulting white precipitate was filtered, washed with water, dried and and recrystallized from $\mathrm{MeOH}$ 4:1 $\mathrm{H}_{2} \mathrm{O}$ to give white sold, yield $70 \%,(0.16 \mathrm{~g}), \mathrm{mp} 183-185{ }^{\circ} \mathrm{C}$. IR (KBr pellet), $\mathrm{cm}^{-1}: \mathrm{v}=3,633$ (free $\mathrm{OH}, \mathrm{BHP}$ ), 3,088, 3,014 (NH), 2,874, 2,930, 2,956 (C-H of $t$-Bu), 1,608 $(\mathrm{C}=\mathrm{N}) .1,252.9(\mathrm{C}=\mathrm{S}) .{ }^{1} \mathrm{H}-\mathrm{NMR}\left(\mathrm{CDCl}_{3}\right), \delta$, ppm: 1.41 $(\mathrm{s}, 18 \mathrm{H}, 2 \times t-\mathrm{Bu}), 3.36(\mathrm{~s}, 2 \mathrm{H}, \mathrm{H}-8), 3.64(\mathrm{~s}, 2 \mathrm{H}, \mathrm{H}-7), 5.18(\mathrm{~s}, 1 \mathrm{H}, \mathrm{OH}, \mathrm{BHP}), 7.08$ (2H, H-3, H-5), 7.14-7.19 (m, 2H, H-12, H-16), 7.21-7.26 (dt, 1H, H-14, $\left.{ }^{3} J_{F-H}=10.4,{ }^{3} J=8,{ }^{4} \mathrm{~J}=4 \mathrm{~Hz}\right), 7.49-7.54$ (dt, $\left.1 \mathrm{H}, \mathrm{H}-15,{ }^{3} \mathrm{~J}=8,{ }^{3} \mathrm{~J}=8 \mathrm{~Hz}\right), 11.75(\mathrm{~b}, \mathrm{NH}) .{ }^{13} \mathrm{C}-\mathrm{NMR}\left(\mathrm{CDCl}_{3}\right), \delta$, ppm: $24.67(1 \mathrm{C}, \mathrm{C}-8), 30.35(6 \mathrm{C}$, $\left.2 \times-\mathrm{C}\left(\mathrm{CH}_{3}\right)_{3}\right), 34.43\left(2 \mathrm{C}, 2 \times-\mathrm{C}\left(\mathrm{CH}_{3}\right)_{3}\right), 36.26(1 \mathrm{C}, \mathrm{C}-7), 116.29\left(\mathrm{~d}, 1 \mathrm{C}, \mathrm{C}-12,{ }^{2} J_{\mathrm{C}-\mathrm{F}}=96 \mathrm{~Hz}\right), 117.65(\mathrm{~d}$, $\left.1 \mathrm{C}, \mathrm{C}-14,{ }^{2} J_{\mathrm{C}-\mathrm{F}}=84 \mathrm{~Hz}\right), 124.25\left(\mathrm{~d}, 1 \mathrm{C}, \mathrm{C}-16,{ }^{4} J_{\mathrm{C}-F}=16 \mathrm{~Hz}\right), 126.06(2 \mathrm{C}, \mathrm{C}-3, \mathrm{C}-5), 126.93$ (1C, C-4), $131.16\left(\mathrm{~d}, 1 \mathrm{C}, \mathrm{C}-15,{ }^{3} J_{\mathrm{C}-F}=36 \mathrm{~Hz}\right), 134.13\left(\mathrm{~d}, 1 \mathrm{C}, \mathrm{C}-11,{ }^{3} J_{\mathrm{C}-F}=40 \mathrm{~Hz}\right), 136.19(2 \mathrm{C}, \mathrm{C}-2, \mathrm{C}-6)$, 150.12 (1C, C-9), 153.25 (1C, C-1), 162.88 (1C, C-13, ${ }^{1} J_{C-F}=1004$ Hz), 169.14 (1C, C-10). HREIMS $m / z 459.1793[\mathrm{M}]+$ (calcd for $\mathrm{C}_{24} \mathrm{H}_{30} \mathrm{O}_{1} \mathrm{~N}_{3} \mathrm{~F}_{1}{ }^{32} \mathrm{~S}_{2} 459.1814$ ).
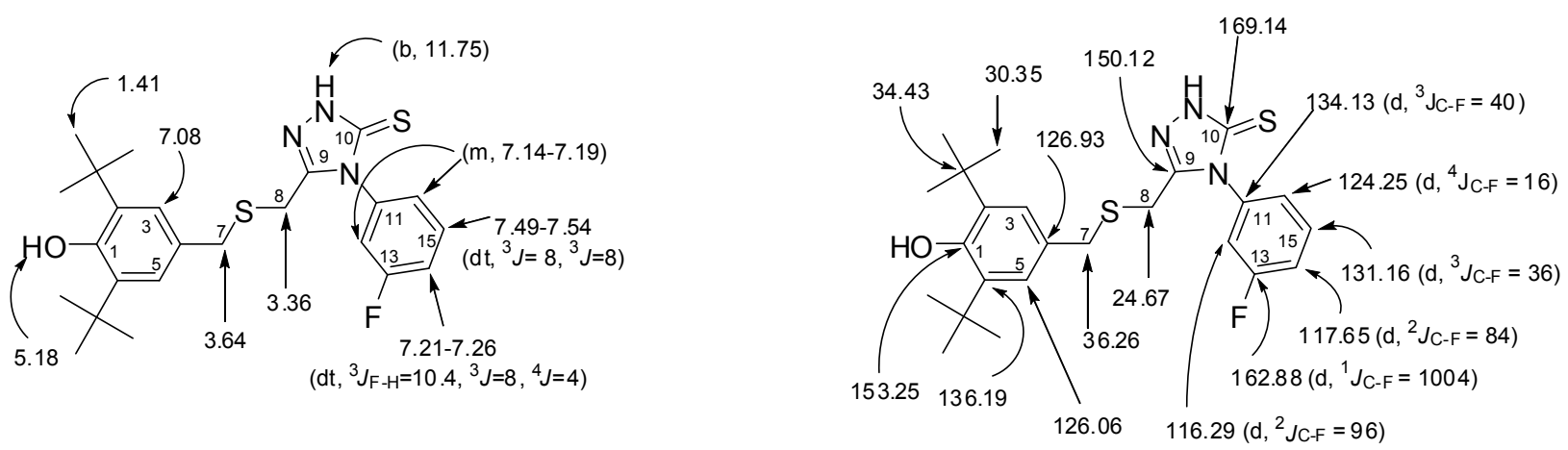

\subsection{X-ray Crystallography}

Diffraction data were measured using a Bruker SMART Apex II CCD area-detector diffractometer (graphite-monochromated Mo K radiation, $=0.71073 \AA$ ). The orientation matrix, unit cell refinement and data reduction were all handled by the Apex 2 software (SAINT integration, SADABS absorption correction) [78]. The structures were solved using direct method in the program SHELXS-97 [79] and were refined by the full matrix least-squares method on F2 with SHELXL-97. Drawings of the molecules were produced with XSEED [80]. Crystal data and refinement are summarized in Table 3.

CCDC 874287 and CCDC 874288 contain the supplementary crystallographic data for $\mathbf{3}$ and $\mathbf{4}$, respectively. These data can be obtained free of charge via http://www.ccdc.cam.ac.uk/conts/ retrieving.html, or from the Cambridge Crystallographic Data Centre, 12 Union Road, Cambridge CB2 1EZ, UK; fax: (+44)-1223-336-033; or e-mail: deposit@ccdc.cam.ac.uk.

\subsection{Antioxidant Assays}

\subsubsection{DPPH Free Radical Scavenging Assay}

DPPH radical scavenging assay was carried out according to the literature [81] with some modifications. To a range of various concentrations $100,10,1,0.1$ and $0.01 \mu \mathrm{M} / \mathrm{mL}$ of samples DPPH 
solution $\left(1.0 \mathrm{~mL}, 200 \mu \mathrm{M}\right.$ in DMSO) was added. $22.03-47.76 \mathrm{mg}\left(1 \times 10^{-4} \mathrm{M}\right)$ of test compound was dissolved in DMSO $(1.0 \mathrm{~mL}, 100 \%)$ as a stock solution. This stock solution was then diluted to a range of final extraction concentrations $100,10,1,0.1$ and $0.01 \mu \mathrm{M}$. A negative control with the same DPPH concentration in DMSO without sample was used. Each assay was carried out in triplicates. The mixture was then incubated in dark for $60 \mathrm{~min}$ at room temperature. Absorbance at $570 \mathrm{~nm}$ for each sample was then measured. Ascorbic acid was used as positive control. The free radical scavenging activity of the compounds was calculated as a percentage of radical inhibition by using the formula:

$$
\text { Percentage of Inhibition }(\%)=\left[\left(\mathrm{A}_{\mathrm{c}}-\mathrm{A}_{\mathrm{s}}\right) / \mathrm{A}_{\mathrm{c}}\right] \times 100
$$

in which $\mathrm{A}_{\mathrm{s}}=$ Absorbance of the compounds/ positive control and $\mathrm{A}_{\mathrm{c}}=$ Absorbance of control (DPPH solution and DMSO). To determine the concentration required to achieve $50 \%$ inhibition $\left(\mathrm{IC}_{50}\right)$ of DPPH radical, the percentage of DPPH inhibition for each compound was plotted against extract concentration.

\subsubsection{Lipid Peroxidation Inhibition Assay}

The lipid peroxidation inhibition assay was carried out according to the reported method with some modifications [82]. Fowl egg yolk, comprising mainly of phospholipids, proteins and triacyglycerol, was used as an alternative to rat liver microsomes and linoleic acid. The reactive mixture for the induction of lipid peroxidation included egg yolk $(1.0 \mathrm{~mL})$ emulsified with phosphate buffer saline $(0.1 \mathrm{M}, \mathrm{pH} 7.4)$, to a final concentration of $12.5 \mathrm{~g} / \mathrm{L}$ and $3,000 \mu \mathrm{M} \mathrm{FeSO}_{4}(200 \mu \mathrm{L})$. Test compound $\left(22.03-47.76 \mathrm{mg}, 1 \times 10^{-4} \mathrm{M}\right)$ was dissolved in DMSO $(1.0 \mathrm{~mL}, 100 \%)$ as a stock solution. This stock solution was then diluted to a range of final extraction concentrations $100,10,1,0.1,0.01$ and $0.001 \mu \mathrm{M}$. Each assay was carried out in triplicates. The mixture was incubated at $37^{\circ} \mathrm{C}$ for $1 \mathrm{~h}$, after which it was treated with freshly prepared trichloracetic acid (TCA, 15\%, $0.5 \mathrm{~mL}$ ) and thiobarbituric acid (TBA, 1\%, $1.0 \mathrm{~mL}$ ). The reaction mixtures were then incubated in boiling water for $10 \mathrm{~min}$. Upon cooling, the mixtures were centrifuged at 3,500 rpm for $10 \mathrm{~min}$. The formation of TBARS was measured by removing $100 \mu \mathrm{L}$ of supernatant and measuring the absorbance at $532 \mathrm{~nm}$. $\alpha$-TOH was used as positive control. The percentage of inhibition was calculated from the following equation:

$$
\% \text { inhibition }=\left[\mathrm{A}_{\mathrm{c}}-\mathrm{A}_{\mathrm{s}} / \mathrm{A}_{\mathrm{c}}\right] \times 100
$$

where $\mathrm{A}_{\mathrm{s}}=$ Absorbance of the compound and $\mathrm{A}_{\mathrm{c}}=$ Absorbance of control.

To determine the concentration required to achieve $50 \%$ inhibition $\left(\mathrm{IC}_{50}\right)$ of phospholipid oxidation in egg yolk, the percentage of lipid peroxidation inhibition was plotted against extract concentration.

\section{Conclusions}

Our design strategy involved combining the good features of two or more antioxidants into one structure. This strategy was applied in an attempt to significantly improve the antioxidant activities of the well-known antioxidant BHT to create novel MPAOs bearing meta electron withdrawing groups. We have demonstrated the improvement in the free-radical scavenging capacity of BHT as determined by inhibition $(25.23 \%)$ of DPPH free radical to be more than two-fold. Compound $\mathbf{5}$ is the most potent compound in the in vitro lipid peroxidation and obviously exhibits promising in vitro inhibition of $\mathrm{Fe}^{2+}$-induced lipid peroxidation of essential oils. The synthesized compounds $\mathbf{3}-\mathbf{5}$ satisfied Lipinski's 
RO5 and ADMET properties. RO5 and ADMET predictions can be important initial steps toward the development of novel pharmaceuticals in the fight against free radicals. Compounds $\mathbf{4}$ and $\mathbf{5}$ have exactly same molecular weight but different polarity and antioxidant activity, and therefore, PASS and MPAO design strategies can be effectively used for finding of compounds with required properties and without undesirable side effects. $m$-Flouro substituents could significantly enhance the antioxidant activity of BHT derivatives like other electron donating groups.

\section{Acknowledgments}

The authors wish to acknowledge the grants (PS190/2008A, PS381/2009B and RG149-11AFR) provided by the University of Malaya to conduct this study.

\section{References and Notes}

1. Schöneich, C. Reactive oxygen species and biological aging: A mechanistic approach. Exp. Gerontol. 1999, 34, 19-34.

2. Sahinoglu, T.; Stevens, C.R.; Bhatt, B.; Blake, D.R. The role of reactive oxygen species in inflammatory disease: Evaluation of methodology. Methods 1996, 9, 628-634.

3. Schöneich, C. Methionine oxidation by reactive oxygen species: Reaction mechanisms and relevance to alzheimer's disease. Biochim. Biophys. Acta 2005, 1703, 111-119.

4. Oka, M.; Tachibana, M.; Noda, K.; Inoue, N.; Tanaka, M.; Kuwabara, K. Relevance of anti-reactive oxygen species activity to anti-inflammatory activity of components of eviprostat, a phytotherapeutic agent for benign prostatic hyperplasia. Phytomedicine 2007, 14, 465-472.

5. Kirkinezos, I.G.; Moraes, C.T. Reactive oxygen species and mitochondrial diseases. Semin. Cell Dev. Biol. 2001, 12, 449-457.

6. de Maria, N.; Colantonl, A.; Fagiuoli, S.; Liu, G.-J.; Rogers, B.K.; Farinati, F.; van Thiel, D.H.; Floyd, R.A. Association between reactive oxygen species and disease activity in chronic hepatitis C. Free Radic. Biol. Med. 1996, 21, 291-295.

7. Smith, C.; Zhang, Y.; Koboldt, C.; Muhammad, J.; Zweifel, B.; Shaffer, A.; Talley, J.; Masferrer, J.; Seibert, K.; Isakson, P. Pharmacological analysis of cyclooxygenase-1 in inflammation. Proc. Natl. Acad. Sci. USA 1998, 95, 13313-13318.

8. Shahidi, F.; Naczk, M.; Griffiths, W. Food Phenolics: Sources, Chemistry, Effects, Applications; Technomic Publishing: Lancaster, PA, USA, 1995.

9. Bandyopadhyay, M.; Chakraborty, R.; Raychaudhuri, U. A process for preparing a natural antioxidant enriched dairy product (sandesh). LWT-Food Sci. Technol. 2007, 40, 842-851.

10. Dacre, J. The metabolism of 3: 5-di-tert-butyl-4-hydroxytoluene and 3: 5-di-tert-butyl-4hydroxybenzoic acid in the rabbit. Biochem. J. 1961, 78, 758-766.

11. Stecher, P. Butylated hydroxytoluene. In The Merck Index, 8th ed.; O'Neil, M.J., Ed.; Merck Research Laboratories: Rahway, NJ, USA, 1968; p. 179.

12. Lazer, E.S.; Wong, H.C.; Possanza, G.J.; Graham, A.G.; Farina, P.R. Antiinflammatory 2,6-di-tert-butyl-4-(2-arylethenyl)phenols. J. Med. Chem. 1989, 32, 100-104. 
13. Song, Y.; Connor, D.; Sercel, A.; Sorenson, R.; Doubleday, R.; Unangst, P.; Roth, B.; Beylin, V.; Gilbertsen, R.; Chan, K. Synthesis, structure-activity relationships, and in vivo evaluations of substituted di-tert-butylphenols as a novel class of potent, selective, and orally active cyclooxygenase-2 inhibitors. 2. 1,3,4- and 1,2,4-Thiadiazole series. J. Med. Chem. 1999, 42, 1161-1169.

14. Marnett, L.J.; Kalgutkar, A.S. Design of selective inhibitors of cyclooxygenase-2 as nonulcerogenic anti-inflammatory agents. Curr. Opin. Chem. Biol. 1998, 2, 482-490.

15. Inagaki, M.; Tsuri, T.; Jyoyama, H.; Ono, T.; Yamada, K.; Kobayashi, M.; Hori, Y.; Arimura, A.; Yasui, K.; Ohno, K. Novel antiarthritic agents with 1,2-isothiazolidine-1,1-dioxide ([gamma]-sultam) skeleton: Cytokine suppressive dual inhibitors of cyclooxygenase-2 and 5-lipoxygenase. J. Med. Chem. 2000, 43, 2040-2048.

16. Unangst, P.C.; Shrum, G.P.; Connor, D.T.; Dyer, R.D.; Schrier, D.J. Novel 1,2,4-oxadiazoles and 1,2,4-thiadiazoles as dual 5-lipoxygenase and cyclooxygenase inhibitors. J. Med. Chem. 1992, 35, 3691-3698.

17. Unangst, P.C.; Connor, D.T.; Cetenko, W.A.; Sorenson, R.J.; Kostlan, C.R.; Sircar, J.C.; Wright, C.D.; Schrier, D.J.; Dyer, R.D. Synthesis and biological evaluation of 5-[[3,5-bis(1,1dimethylethyl)-4-hydroxyphenyl]methylene]oxazoles, -thiazoles, and -imidazoles: Novel dual 5-lipoxygenase and cyclooxygenase inhibitors with antiinflammatory activity. J. Med. Chem. 1994, 37, 322-328.

18. Mullican, M.D.; Wilson, M.W.; Conner, D.T.; Kostlan, C.R.; Schrier, D.J.; Dyer, R.D. Design of 5-(3,5-di-tert-butyl-4-hydroxyphenyl)-1,3,4-thiadiazoles, -1,3,4-oxadiazoles, and -1,2,4-triazoles as orally active, nonulcerogenic antiinflammatory agents. J. Med. Chem. 1993, 36, 1090-1099.

19. Leventis, I.; Andreadou, I.; Papalois, A.; Sfiniadakis, I.; Gorgoulis, V.; Korkolis, D.; Hadjipavlou-Litina, D.; Kourounakis, P.; Fotiadis, C. A novel antioxidant non-steroidal anti-inflammatory agent protects rat liver against ischemia-reperfusion injury. In Vivo 2004, 18, 161-169.

20. Weber, V.; Rubat, C.; Duroux, E.; Lartigue, C.; Madesclaire, M.; Coudert, P. New 3- and 4-hydroxyfuranones as anti-oxidants and anti-inflammatory agents. Bioorg. Med. Chem. 2005, 13, 4552-4564.

21. Amorati, R.; Lucarini, M.; Mugnaini, V.; Pedulli, G. Antioxidant activity of $o$-bisphenols: The role of intramolecular hydrogen bonding. J. Org. Chem. 2003, 68, 5198-5204.

22. Moore, G.; Swingle, K. 2,6-di-tert-butyl-4-(2-thenoyl)phenol(r-830): A novel nonsteroidal anti-inflammatory agent with antioxidant properties. Inflamm. Res. 1982, 12, 674-683.

23. Grosso, P.; Vogl, O. Functional polymers. Polym. Bull. 1985, 14, 245-250.

24. Zhang, H. Structure-activity relationships and rational design strategies for radical-scavenging antioxidants. Curr. Comput. Aided Drug Des. 2005, 1, 257-273.

25. Zhang, H.-Y.; Yang, D.-P.; Tang, G.-Y. Multipotent antioxidants: From screening to design. Drug Discov. Today 2006, 11, 749-754.

26. Kato, T.; Ozaki, T.; Tamura, K.; Suzuki, Y.; Akima, M.; Ohi, N. Novel calcium antagonists with both calcium overload inhibition and antioxidant activity. 1. 2-(3,5-di-tert-butyl-4-hydroxyphenyl)3-(aminopropyl)thiazolidinones. J. Med. Chem. 1998, 41, 4309-4316. 
27. Dobek, A.; Klayman, D.; Dickson, E., Jr.; Scovill, J.; Oster, C. Thiosemicarbazones of 2-acetylpyridine, 2-acetylquinoline, 1-and 3-acetylisoquinoline and related compounds as inhibitors of clinically significant bacteria in vitro. Arzneimittelforschung 1983, 33, 1583-1591.

28. Eid, A.I.; Ragab, F.A.; El-Ansary, S.L.; El-Gazayerly, S.M.; Mourad, F.E. Synthesis of new 7-substituted 4-methylcoumarin derivatives of antimicrobial activity. Arch. Pharm. 1994, 327, 211-213.

29. Liesen, A.P.; de Aquino, T.M.; Carvalho, C.S.; Lima, V.T.; de Araújo, J.M.; de Lima, J.G.; de Faria, A.R.; de Melo, E.J.T.; Alves, A.J.; Alves, E.W.; et al. Synthesis and evaluation of anti-toxoplasma gondii and antimicrobial activities of thiosemicarbazides, 4-thiazolidinones and 1,3,4-thiadiazoles. Eur. J. Med. Chem. 2010, 45, 3685-3691.

30. Kus, C.; Ayhan-Kilcigil, G.; Eke, B.; iŞcan, M. Synthesis and antioxidant properties of some novel benzimidazole derivatives on lipid peroxidation in the rat liver. Arch. Pharm. Res. 2004, 27 , 156-163.

31. Hussain, S.; Sharma, J.; Amir, M. Synthesis and antimicrobial activities of 1,2,4-triazole and 1,3,4-thiadiazole derivatives of 5-amino-2-hydroxybenzoic acid. E-J. Chem. 2008, 5, 963-968.

32. Vasoya, S.L.; Paghdar, D.J.; Chovatia, P.T.; Joshi, H.S. Synthesis of some new thiosemicarbazide and 1,3,4-thiadiazole heterocycles bearing benzo[b]thiophene nucleus as a potent antitubercular and antimicrobial agents. J. Sci. Islam. Repub. Iran 2005, 16, 33-36.

33. Rzeski, W.; Matysiak, J.; Kandefer-Szerszen, M. Anticancer, neuroprotective activities and computational studies of 2-amino-1,3,4-thiadiazole based compound. Bioorg. Med. Chem. 2007, 15, 3201-3207.

34. Abdel-Rahman, T.M. Synthesis, reactions, and anticancer activity of some 1,3,4-thiadiazole/ thiadiazine derivatives of carbazole. Phosphorus Sulfur Silicon Relat. Elem. 2006, 181, 1737-1754.

35. Khan, I.; Ali, S.; Hameed, S.; Rama, N.H.; Hussain, M.T.; Wadood, A.; Uddin, R.; Ul-Haq, Z.; Khan, A.; Ali, S.; et al. Synthesis, antioxidant activities and urease inhibition of some new 1,2,4-triazole and 1,3,4-thiadiazole derivatives. Eur. J. Med. Chem. 2010, 45, 5200-5207.

36. Palaska, E.; Sahin, G.; Kelicen, P.; Durlu, N.T.; Altinok, G. Synthesis and anti-inflammatory activity of 1-acylthiosemicarbazides, 1,3,4-oxadiazoles, 1,3,4-thiadiazoles and 1,2,4-triazole-3thiones. Il Farmaco 2002, 57, 101-107.

37. Navidpour, L.; Shafaroodi, H.; Abdi, K.; Amini, M.; Ghahremani, M.H.; Dehpour, A.R.; Shafiee, A. Design, synthesis, and biological evaluation of substituted 3-alkylthio-4,5-diaryl-4h-1,2,4triazoles as selective COX-2 inhibitors. Bioorg. Med. Chem. 2006, 14, 2507-2517.

38. Wujec, M.; Pitucha, M.; Dobosz, M.; Kosikowska, U.; Malm, A. Synthesis and potential antimycotic activity of 4-substituted-3-(thiophene-2-yl-methyl)-delta2-1,2,4-triazoline-5-thiones. Acta Pharm. 2004, 54, 251-260.

39. Kajiyama, T.; Ohkatsu, Y. Effect of meta-substituents of phenolic antioxidants-Proposal of secondary substituent effect. Polym. Degrad. Stab. 2002, 75, 535-542.

40. Hossain, M.; Shaha, S.; Aziz, F. Antioxidant potential study of some synthesized $N$-heterocycles. Bangladesh Med. Res. Counc. Bull. 2009, 35, 49-52.

41. Ferreira, I.; Queiroz, M.; Vilas-Boas, M.; Estevinho, L. Evaluation of the antioxidant properties of diarylamines in the benzo $[b]$ thiophene series by free radical scavenging activity and reducing power. Bioorg. Med. Chem. Lett. 2006, 16, 1384-1387. 
42. Accelrys Homepage. Available online: http://accelrys.com/ (accessed on 12 January 2012).

43. Phillips, E.; Wasson, R.C. Phenols as corrosion inhibitors and antioxidants. EP330613A2, 30 August 1989.

44. Macleay, R.E.; Myers, T.N. Multipurpose polymer bound stabilizers. EP303986A2, 7 July 1993.

45. Akinchan, N.T.; West, D.X.; Yang, Y.; Salberg, M.M.; Klein, T.L. Magnetic and spectroscopic properties of copper(II) complexes with 1-salicoyl-4-phenylthiosemicarbazide. Transit. Met. Chem. 1995, 20, 481-484.

46. Angelusiu, M.V.; Almajan, G.L.; Rosu, T.; Negoiu, M.; Almajan, E.-R.; Roy, J. Copper(II) and uranyl(II) complexes with acylthiosemicarbazide: Synthesis, characterization, antibacterial activity and effects on the growth of promyelocytic leukemia cells HL-60. Eur. J. Med. Chem. 2009, 44, 3323-3329.

47. Jampílek, J.; Doležal, M.; Kuneš, J.; Raich, I.; Liška, F. 4-substituted aryl bromides coupling with 4-methoxybenzene-1-thiol by means of copper catalysts. Chem. Papers 2005, 59, 178-181.

48. PharmaExpert. Available online: http://www.pharmaexpert.ru/passonline/ (accessed on 4 March 2012).

49. Parasuraman, S. Prediction of activity spectra for substances. J. Pharmacol. Pharmacother. 2011, 2, 52-53.

50. Stepanchikova, A.V.; Lagunin, A.A.; Filimonov, D.A.; Poroikov, V.V. Prediction of biological activity spectra for substances: Evaluation on the diverse sets of drug-like structures. Curr. Med. Chem. 2003, 10, 225-233.

51. Anzali, S.; Barnickel, G.; Cezanne, B.; Krug, M.; Filimonov, D.; Poroikov, V. Discriminating between drugs and nondrugs by prediction of activity spectra for substances (pass). J. Med. Chem. 2001, 44, 2432-2437.

52. Lipinski, C.A.; Lombardo, F.; Dominy, B.W.; Feeney, P.J. Experimental and computational approaches to estimate solubility and permeability in drug discovery and development settings. Adv. Drug Deliv. Rev. 1997, 23, 3-25.

53. Veber, D.F.; Johnson, S.R.; Cheng, H.-Y.; Smith, B.R.; Ward, K.W.; Kopple, K.D. Molecular properties that influence the oral bioavailability of drug candidates. J. Med. Chem. 2002, 45, 2615-2623.

54. Tafazoli, S.; Wright, J.S.; O'Brien, P.J. Prooxidant and antioxidant activity of vitamin e analogues and troglitazone. Chem. Res. Toxicol. 2005, 18, 1567-1574.

55. Massaeli, H.; Sobrattee, S.; Pierce, G.N. The importance of lipid solubility in antioxidants and free radical generating systems for determining lipoprotein peroxidation. Free Radic. Biol. Med. 1999, 26, 1524-1530.

56. Bakht, M.A.; Yar, M.S.; Abdel-Hamid, S.G.; Al Qasoumi, S.I.; Samad, A. Molecular properties prediction, synthesis and antimicrobial activity of some newer oxadiazole derivatives. Eur. J. Med. Chem. 2010, 45, 5862-5869.

57. Ingold, K.; Burton, G. Vitamin E: Or why we don't go rancid. J. Chin. Chem. Soc. 1992, 39, 199-204.

58. Mishra, H.; Singh, N.; Lahiri, T.; Misra, K. A comparative study on the molecular descriptors for predicting drug-likeness of small molecules. Bioinformation 2009, 3, 384-388. 
59. Lipinski, C.A. Lead- and drug-like compounds: The rule-of-five revolution. Drug Discov. Today Technol. 2004, 1, 337-341.

60. Refsgaard, H.H.F.; Jensen, B.F.; Brockhoff, P.B.; Guldbrandt, M.; Christensen, M.S. In silico prediction of membrane permeability from calculated molecular parameters. J. Med. Chem. 2005, $48,805-811$.

61. Wang, R.; Fu, Y.; Lai, L. A new atom-additive method for calculating partition coefficients. J. Chem. Inf. Comput. Sci. 1997, 37, 615-621.

62. Eklund, P.C.; Langvik, O.K.; Warna, J.P.; Salmi, T.O.; Willfor, S.M.; Sjoholm, R.E. Chemical studies on antioxidant mechanisms and free radical scavenging properties of lignans. Org. Biomol. Chem. 2005, 3, 3336-3347.

63. Sharma, O.P.; Bhat, T.K. Dpph antioxidant assay revisited. Food Chem. 2009, 113, 1202-1205.

64. Frankel, E. Lipid Oxidation, 2 ed.; Oily Press Lipid Library Bridgewater: Bridgewater, UK, 2005; Volume 10, pp. 1-470.

65. Nawar, W. Lipids, Chapter 5. In Food Chemistry, 3rd ed.; Fennema, O.R., Ed.; Marcel Dekker, Inc.: New York, NY, USA, 1996; pp. 254-299.

66. Kus, C.; Ayhan-KIlcIgil, G.; Özbey, S.; Kaynak, F.; Kaya, M.; Çoban, T.; Can-Eke, B. Synthesis and antioxidant properties of novel $N$-methyl-1,3,4-thiadiazol-2-amine and 4-methyl-2h-1,2,4triazole-3(4h)-thione derivatives of benzimidazole class. Bioorg. Med. Chem. 2008, 16, 4294-4303.

667. Lucarini, M.; Pedrielli, P.; Pedulli, G.F.; Valgimigli, L.; Gigmes, D.; Tordo, P. Bond dissociation energies of the N-H bond and rate constants for the reaction with alkyl, alkoxyl, and peroxyl radicals of phenothiazines and related compounds. J. Am. Chem. Soc. 1999, 121, 11546-11553.

68. Scott, G. Antioxidants. Bull. Chem. Soc. Jpn. 1988, 61, 165-170.

69. Escobar-Valderrama, J.; Garcia-Tapia, J.; Ramirez-Ortiz, J.; Rosales, M.; Toscano, R.; Valdes-Martinez, J. Crystal, molecular and electronic structure of 1-h-3-methyl-4-amine-5-thione1,2,4-triazol. Can. J. Chem. 1989, 67, 198-201.

70. Matsuura, T.; Ohkatsu, Y. Phenolic antioxidants: Effect of $O$-benzyl substituents. Polym. Degrad. Stab. 2000, 70, 59-63.

71. Amorati, R.; Ferroni, F.; Pedulli, G.F.; Valgimigli, L. Modeling the co-antioxidant behavior of monofunctional phenols. Applications to some relevant compounds. J. Org. Chem. 2003, 68, 9654-9658.

72. Huang, D.; Ou, B.; Hampsch-Woodill, M.; Flanagan, J.; Deemer, E. Development and validation of oxygen radical absorbance capacity assay for lipophilic antioxidants using randomly methylated-cyclodextrin as the solubility enhancer. J. Agric. Food Chem. 2002, 50, 1815-1821.

73. McClements, D.; Decker, E. Lipid oxidation in oil in water emulsions: Impact of molecular environment on chemical reactions in heterogeneous food systems. J. Food Sci. 2000, 65, 1270-1282.

74. Alamed, J. Impact of Chemical and Physical Properties on the Ability of Antioxidants to Inhibit Lipid Oxidation in Foods; University of Massachusetts Amherst, Amherst, MA, USA, 2008.

75. Decker, E.A. Strategies for manipulating the prooxidative/antioxidative balance of foods to maximize oxidative stability. Trends Food Sci. Technol. 1998, 9, 241-248.

76. Khan, I.; Ali, S.; Hameed, S.; Rama, N.; Hussain, M.; Wadood, A.; Uddin, R.; Ul-Haq, Z.; Khan, A. Synthesis, antioxidant activities and urease inhibition of some new 1,2,4-triazole and 1,3,4-thiadiazole derivatives. Eur. J. Med. Chem. 2010, 45, 5200-5207. 
77. Hilton, J. Antioxidants: Function, types and necessity of inclusion in pet foods. Can. Vet. J. 1989, 30, 682-684.

78. Bruker. APEX2 and SAINT; Bruker AXS Inc.: Madison, WI, USA, 2007.

79. Sheldrick, G. A short history of shelx. Acta Crystallogr. A 2008, 64, 112-122.

80. Barbour, L.J. X-seed-A software tool for supramolecular crystallography. J. Supramol. Chem. 2001, 1, 189-191.

81. Blois, M.S. Antioxidant determination by the use of a stable free radical. Nature 1958, 181, 1199-1200.

82. Daker, M.; Abdullah, N.; Vikineswary, S.; Goh, P.C.; Kuppusamy, U.R. Antioxidant from maize and maize fermented by Marasmiellus sp. As stabiliser of lipid-rich foods. Food Chem. 2008, 107, 1092-1098

Sample Availability: Samples of the compounds 1-3 are available from the authors.

(C) 2012 by the authors; licensee MDPI, Basel, Switzerland. This article is an open access article distributed under the terms and conditions of the Creative Commons Attribution license (http://creativecommons.org/licenses/by/3.0/). 